\title{
TREATMENT OF ADDISON'S DISEASE WITH DESOXY-CORTICOSTERONE ACETATE, A SYNTHETIC ADRENAL CORTICAL HORMONE (PRELIMINARY REPORT) ${ }^{1}$
}

\author{
By GEORGE W. THORN, R. PALMER HOWARD ${ }^{2}$ AND KENDALL EMERSON, JR. \\ (From the Chemical Division, Medical Clinic, Johns Hopkins University and Hospital, \\ Baltimore)
}

(Received for publication February 21, 1939)

The successful preparation of extracts of the adrenal cortex which possessed the property of maintaining adrenalectomized animals $(1,2,3)$ stimulated attempts to isolate the substance or substances responsible for this activity. Reichstein has pointed out in his review article (4) that, thus, far, several steroid compounds have been isolated from adrenal cortical extracts by Kendall, Reichstein, Wintersteiner, Pfiffner, and Grollman. At least 3 of these compounds have been shown to be capable, on injection, of maintaining adrenalectomized animals in good condition (4).

The small quantity of active material present in the adrenal cortex and the necessarily limited supply of adrenal glands restrict greatly the quantity of crystalline material which may be obtained from this natural source. The use of crystalline compounds would be of distinct advantage in the treatment of patients with Addison's disease because of the practical difficulties encountered in attempting to prepare extracts of uniform potency. It appears that a synthetic preparation offers the most likely possibility of obtaining an adequate quantity of crystalline material possessing " cortinlike" properties.

In 1937 Steiger and Reichstein (5) announced the preparation of desoxy-corticosterone acetate ( $\Delta^{4}$-pregnene-21-ol-3, 20-dione, acetate) from stigmasterol. Recently, Reichstein and von Euw (6) have succeeded in obtaining desoxy-corticosterone from an extract of beef adrenals, thus establishing the natural occurrence of this compound. The effectiveness of desoxy-corticosterone acetate (synthetic) in maintaining bilaterally adrenalectomized dogs $(7,8)$ prompted us to investigate the possibility of using this compound

1 This study was aided by a grant from the Committee on Research in Endocrinology, National Research Council.

2 Jacques Loeb Fellow in Medicine. in the treatment of patients with Addison's disease.

In this report we have studied the effect of subcutaneous or intramuscular injections of a solution of desoxy-corticosterone acetate ${ }^{8}$ in oil in 8 patients with Addison's disease. Because of the known beneficial effect of added sodium salts ( 9 , 10) on the course of the disease, particular care was taken to limit the sodium chloride intake of the patients during these studies. However, in 2 of the patients (C.N. and J.Z.) it was considered advisable to undertake desoxy-corticosterone acetate treatment, while these patients were receiving sodium chloride therapy. Subsequently, it was possible to discontinue completely the additional sodium chloride therapy during the course of treatment with desoxy-corticosterone acetate.

No attempt was made to reduce the daily intake of potassium (11) in any of the patients. It is obvious that a diet of low sodium chloride and normal or high potassium content is not advocated for clinical application, but is desirable for critical evaluation of the effectiveness of a compound suspected of possessing "cortin-like" activity. It is also apparent that the patient's requirement of hormone on such a regimen will be much greater than under conditions in which the diet is supplemented by the addition of sodium salts, or restricted in potassium content.

\section{METHODS}

All of the patients were studied on the metabolism ward of the Johns Hopkins Hospital. For the purpose of balance studies each patient was provided with a constant diet and a constant fluid intake, the same items of food being ingested each day throughout the period of investigation. A quantity of food sufficient for a 5-day period was purchased at one time and an aliquot

8 The synthetic desoxy-corticosterone acetate (Percorten) used in this study was supplied by Messrs. Ciba through the courtesy of Doctors $K$. Miescher and $E$. Oppenheimer. 


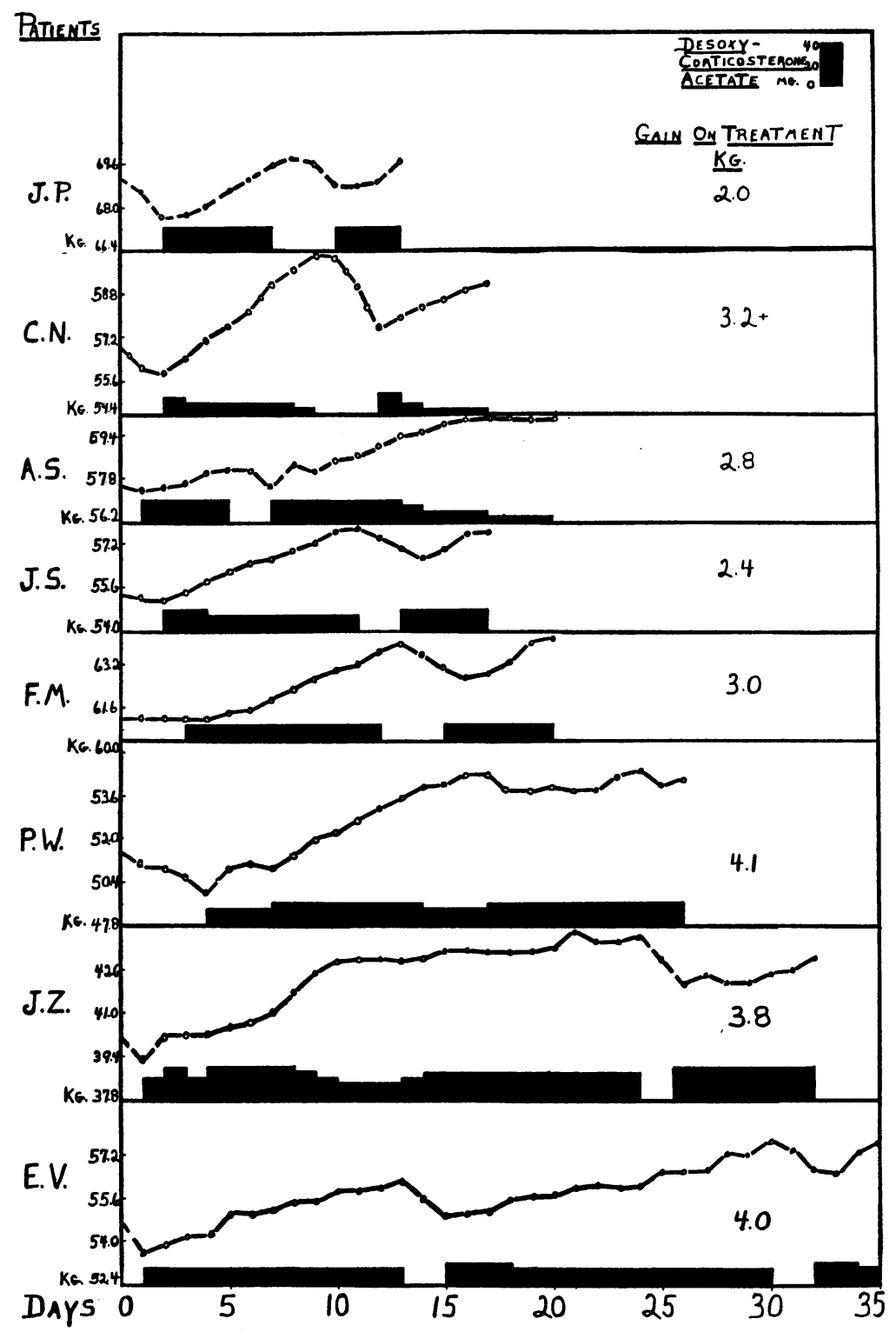

Fig. 1. The Effect of Desoxy-corticosterone Acetate Treatment on the Body Weight of Patients with Addison's Disease

of one day's entire diet was analyzed for its mineral content. Since the food was prepared without added seasoning, each patient was permitted an accurately weighed quantity of sodium chloride ( 3 grams daily) which was added to the food immediately before being ingested.

At 10 p.m. each evening the patients voided and were then weighed. No food or fluid was permitted during the night. At 7 a.m. before arising, the blood pressure was determined. The patients then voided (completing the 24-hour period) and were weighed. By this method it was possible to obtain an approximate value for the rate of insensible water loss during a 9-hour period.
Specimens of blood for chemical analyses were withdrawn under oil and without stasis from the antecubital vein, the patients having been fasted for 15 hours previously. The following determinations were made: hematocrit, serum concentration of sodium (12), chloride (13) and potassium $(14,15)$, carbon dioxide combining power of the serum (16), blood nonprotein nitrogen (17) and blood sugar (Folin-Wu).

Plasma volume measurements were made according to the technic of Gregersen and Gibson $(18,19)$ using the dye, T-1824. Duplicate samples of blood for serum were withdrawn at intervals of 20 minutes for 2 hours following the injection of the dye. The concentration 
of the dye in the samples of serum was determined by means of the Evelyn photoelectric colorimeter $(20,21)$.

Twenty-four-hour urine specimens were collected, preserved with toluol, and later analyzed for sodium (12), chloride (13), potassium $(14,15)$, inorganic phosphorus (22), and total nitrogen (macro-Kjeldahl) content.

Following a control period, the patients were treated with subcutaneous injections of a solution of desoxycorticosterone acetate in oil. Later, desoxy-corticosterone acetate treatment was discontinued for a period of from 24 to 72 hours. The length of the withdrawal period was determined by the patient's clinical condition. Subsequently, desoxy-corticosterone acetate treatment was resumed. During each of these periods the patient's clinical condition, body weight, blood pressure, plasma volume, plasma concentration, and renal excretion of electrolytes were observed. To control the possible psychological effect of discontinuing and resuming treatment, subcutaneous injections of a placebo were substituted for injections of hormone during the withdrawal periods.

\section{OBSERVATIONS}

The specific changes which occurred as the result of desoxy-corticosterone acetate treatment are recorded in the charts and tables. A more detailed account of the effect of treatment may be found in the résumé attached to the individual protocols.

\section{Body weight}

A change in body weight constitutes one of the most sensitive indicators of a change in the clinical status of patients with Addison's disease. Improvement in clinical condition is regularly accompanied by weight gain and a relapse is associated with weight loss.

In every patient treatment with desoxy-corticosterone acetate resulted in a marked gain in body weight which paralleled clinical improvement (Figure 1). A significant increase in weight was observed within 48 hours after treatment was begun. Withdrawal of treatment resulted in a prompt and progressive decrease in weight which was associated with decreased muscular efficiency, loss of appetite, and the onset of symptoms of adrenal insufficiency. Institution of treatment at this time prevented further weight loss and within a period of 48 hours resulted in weight gain. These sudden changes in body weight appeared to be directly related to changes in mineral and water balance, weight gain being invariably associated with a retention of sodium, chloride, and water, and weight loss usually being accompanied by a diuresis and increased renal excretion of sodium and chloride. Occasionally, a slight decrease in body weight and a diuresis were noted on the first or second day of treatment despite a retention of sodium and chloride. This unexpected decrease in weight resulted from the marked potassium diuresis occasioned by the institution of treatment.

The diet of constant mineral and caloric content limited to some extent the total weight gain which was possible during the experimental period, and the weight increments tabulated in Figure 1 were modified by the weight loss which occurred during the withdrawal periods.

\section{Blood pressure}

A change in blood pressure usually accompanies a significant change in the clinical status of patients with Addison's disease although frequently a considerable delay in blood pressure response is observed both during remission and relapse. A rapid increase in blood pressure from shock level is usually noted in patients in crisis following adequate treatment with infusions of sodium chloride and glucose, or adrenal cortical extract, or following a combination of both forms of therapy. The

TABLE I

The effect of desoxy-corticosterone acetate treatment on the blood pressure of patients with Addison's disease

\begin{tabular}{|c|c|c|c|}
\hline \multirow[b]{2}{*}{ Patients } & \multicolumn{3}{|r|}{ Blood pressure* } \\
\hline & $\begin{array}{l}\text { Previous } \\
\text { to treat- } \\
\text { mentf }\end{array}$ & $\begin{array}{l}\text { During } \\
\text { treat- } \\
\text { ment }\end{array}$ & Treatment \\
\hline 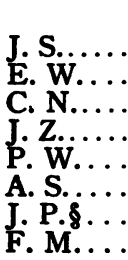 & $\begin{array}{r}\text { mm. } \mathrm{Hg}_{\mathrm{g}} \\
96 / 72 \\
94 / 65 \\
95 / 59 \\
93 / 59 \\
92 / 61 \\
105 / 66 \\
129 / 91 \\
92 / 60\end{array}$ & $\begin{array}{c}\mathrm{mm} . H g \\
133 / 80 \\
130 / 80 \\
110 / 70 \\
106 / 66 \\
103 / 78 \\
114 / 70 \\
133 / 81 \\
112 / 70\end{array}$ & $\begin{array}{l}10 \mathrm{mgm} \text {. daily for } 120 \text { days } \\
10 \mathrm{mgm} \text {. daily for } 150 \text { days } \\
3 \mathrm{mgm} \text {. daily for } 40 \text { days } \\
25 \mathrm{mgm} \text {. daily for } 20 \text { days } \\
20 \mathrm{mgm} \text {. daily for } 20 \text { days } \\
10 \mathrm{mgm} \text {. daily for } 30 \text { days } \\
20 \mathrm{mgm} \text {. daily for } 8 \text { days } \\
15 \mathrm{mgm} \text {. daily for } 90 \text { days }\end{array}$ \\
\hline
\end{tabular}

* All blood pressure measurements were made at 7 a.m. with the patients resting quietly in bed. The values in the table represent the average of 3 determinations made on 3 successive days during the period noted.

t These values represent the blood pressure level at the time desoxy-corticosterone acetate treatment was substituted.

$\ddagger$ These values represent the measurements obtained during a period in which the patients were being maintained on desoxy-corticosterone acetate, without added sodium chloride therapy.

\& This patient was known to have hypertension which antedated the onset of symptoms of adrenal insufficiency. 


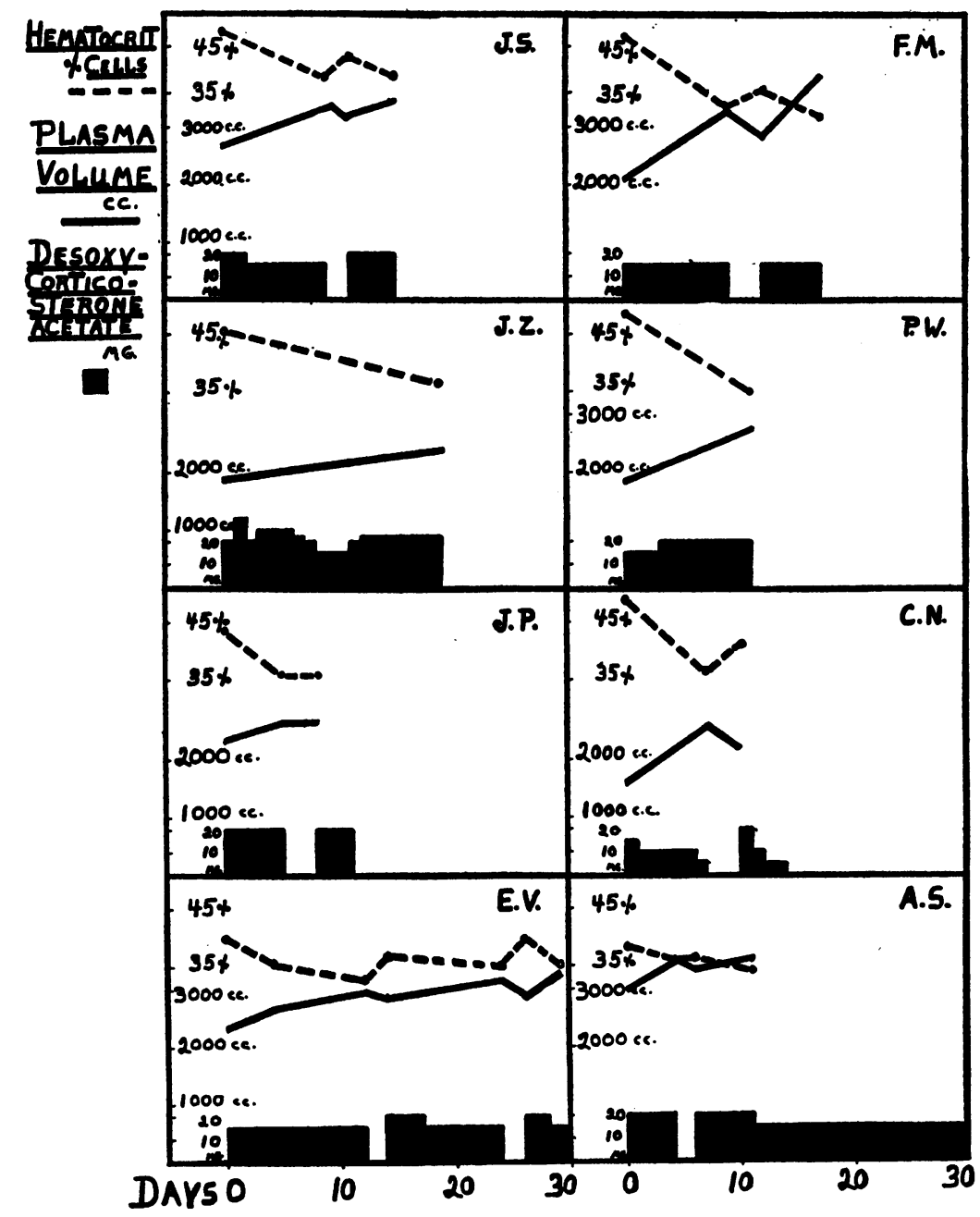

Fig. 2. The Effect of Desoxy-corticosterone Acetate Treatment on the Plasma Volume and Hematocrit of Patients with Addison's Disease

difficulty, subsequently, with which the blood pressure is raised to a normal level and maintained at that level is well known.

Treatment with desoxy-corticosterone acetate ( 3 to $25 \mathrm{mgm}$. daily) for periods of from 8 to 50 days resulted in increased blood pressure in all of the patients (Table I). In 1 patient (F.M.) no increase in blood pressure was observed until treatment had been continued for more than 20 days. In all instances an increase in blood pressure was associated with increased strength, improved appetite, and sense of well-being.

\section{Pulse rate and body temperature}

Treatment with desoxy-corticosterone acetate resulted in no appreciable change in either the pulse rate or body temperature in 6 of the patients. In 2 patients, continued daily injections of 20 to $25 \mathrm{mgm}$. of desoxy-corticosterone acetate in sesame oil (4 to $5 \mathrm{cc}$. of oil daily) resulted, after 15 to 20 days of treatment in an increased rectal temperature $\left(101^{\circ}\right.$ to $102^{\circ} \mathrm{F}$.) and in tachycardia. Withdrawal of treatment was accompanied by a rapid return of temperature and pulse rate to normal. Subsequently, injections of the same quantity of desoxy-corticosterone acetate in sesame oil (4 to $5 \mathrm{cc}$.) again resulted in a febrile response. The intradermal injection of sesame oil alone was followed by a very marked local skin reaction in these patients. In control subjects, a negative skin reaction was observed with the same quantity of oil. Other patients 
TABLE II

The effect of desoxy-corticosterone acetate on the total plasma content of sodium, chloride, and potassium

\begin{tabular}{|c|c|c|c|c|c|c|c|c|c|c|c|c|}
\hline \multirow{2}{*}{ Patient } & \multicolumn{3}{|c|}{ Before treatment } & \multicolumn{3}{|c|}{ During treatment } & \multicolumn{3}{|c|}{$\begin{array}{l}\text { Withdrawal of treatment } \\
48 \text { to } 72 \text { hours }\end{array}$} & \multicolumn{3}{|c|}{ Treatment restored } \\
\hline & $\begin{array}{c}\text { Plasma } \\
\text { level }\end{array}$ & $\begin{array}{l}\text { Plasma } \\
\text { volume }\end{array}$ & $\begin{array}{c}\text { Total } \\
\text { plasma } \\
\text { content }\end{array}$ & $\begin{array}{c}\text { Plasma } \\
\text { level }\end{array}$ & $\begin{array}{l}\text { Plasma } \\
\text { volume }\end{array}$ & $\begin{array}{c}\text { Total } \\
\text { plasma } \\
\text { content }\end{array}$ & $\begin{array}{c}\text { Plasma } \\
\text { level }\end{array}$ & $\begin{array}{l}\text { Plasma } \\
\text { volume }\end{array}$ & $\begin{array}{c}\text { Total } \\
\text { plasma } \\
\text { content }\end{array}$ & $\begin{array}{c}\text { Plasma } \\
\text { level } \\
\text { content }\end{array}$ & $\begin{array}{l}\text { Plasma } \\
\text { volume }\end{array}$ & $\begin{array}{c}\text { Total } \\
\text { plasma } \\
\text { content }\end{array}$ \\
\hline \multirow[t]{2}{*}{ J. S. } & $\begin{array}{l}\text { m. eq. per } \\
\text { liter } \\
\mathrm{Na} 138.5\end{array}$ & $c c$. & $\begin{array}{c}\text { m. eq. } \\
\mathrm{Na} \mathrm{378.0} \\
\end{array}$ & $\begin{array}{l}\text { m. eq. per } \\
\text { liter } \\
\mathrm{Na} 141.8\end{array}$ & $c c$. & $\begin{array}{c}\text { m. eq. } \\
\mathrm{Na} 476.8 \\
\end{array}$ & $\left|\begin{array}{l}\text { m. eq. per } \\
\text { liter } \\
\mathrm{Na} 140.4\end{array}\right|$ & $c c$. & 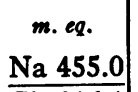 & $\begin{array}{c}\text { m.eq. } \\
\mathrm{Na} 142.7\end{array}$ & $c c$. & 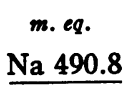 \\
\hline & $\begin{array}{lr}\mathrm{Cl} & 96.4 \\
\mathrm{~K} & 6.5\end{array}$ & 2730 & $\begin{array}{ll}\mathrm{Cl} & 263.2 \\
\mathrm{~K} & 177\end{array}$ & $\begin{array}{ll}C l & 102.0 \\
Y & 6\end{array}$ & 3370 & $\begin{array}{ll}\text { Cl } & 343.9 \\
& 20.6\end{array}$ & $\mathrm{Cl} \quad 97.6$ & 3240 & $\begin{array}{lr}\mathrm{Cl} & 316.1 \\
\mathrm{~K} & 220\end{array}$ & 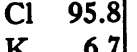 & 3440 & $\begin{array}{lr}\text { Cl } & 329.6 \\
\mathrm{~K} & 23.1\end{array}$ \\
\hline \multirow[t]{2}{*}{ E. V. } & $\begin{array}{ll}\mathrm{Na} & 134.8 \\
\mathrm{Cl} & 101.2\end{array}$ & & $\frac{\mathrm{Na} 367.0}{\mathrm{Cl}}$ & $\begin{array}{ll}\mathrm{Na} & 142.7 \\
\mathrm{Cl} & 100.6\end{array}$ & 3150 & $\frac{\mathrm{Na} 449.0}{\mathrm{Cl} 316.9}$ & $\left|\begin{array}{rr}\mathrm{Na} & 137.4 \\
\mathrm{Cl} & 96.8\end{array}\right|$ & 2950 & 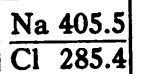 & $\begin{array}{ll}\mathrm{Na} & 139.3 \\
\mathrm{Cl} & 100.4\end{array}$ & 3240 & $\frac{\mathrm{Na} 451.5}{\mathrm{Cl} 325.3}$ \\
\hline & K $\quad 4.2$ & & $\begin{array}{ll}\mathrm{K} & 11.4 \\
\end{array}$ & $\begin{array}{ll}\mathrm{K} & 5.6\end{array}$ & & $\begin{array}{ll}\mathrm{K} & 17.8 \\
\end{array}$ & $\begin{array}{ll}\mathrm{K} & 4.9\end{array}$ & & $\begin{array}{ll}\mathbf{K} & 14.5\end{array}$ & $\begin{array}{ll}K & 4.9\end{array}$ & & $\begin{array}{ll}\mathrm{K} \quad 15.9\end{array}$ \\
\hline \multirow[t]{2}{*}{ F. M. } & $\mathrm{Na} 135.6$ & & $\mathrm{Na} 282.7$ & $\mathrm{Na} 136.7$ & & $\mathrm{Na} 450.1$ & $\mathrm{Na} 137.4$ & & $\mathrm{Na} 397.5$ & $\mathrm{Na} 139.2$ & & $\mathrm{Na} 543.5$ \\
\hline & $\begin{array}{lr}\mathrm{Cl} & 92.8 \\
\mathrm{~K} & 6.7\end{array}$ & 2085 & $\begin{array}{lr}\mathrm{Cl} & 193.7 \\
\mathrm{~K} & 13.9\end{array}$ & $\left|\begin{array}{lr}\mathrm{Cl} & 97.8 \\
\mathrm{~K} & 4.2\end{array}\right|$ & 3300 & $\begin{array}{lr}\mathrm{Cl} & 322.4 \\
\mathrm{~K} & 13.8\end{array}$ & $\left|\begin{array}{rr}\mathrm{Cl} & 96.4 \\
\mathrm{~K} & 6.3\end{array}\right|$ & 2890 & $\begin{array}{lr}\mathrm{Cl} & 278.5 \\
\mathrm{~K} & 18.1\end{array}$ & $\begin{array}{lr}\mathrm{Cl} & 101.2 \\
\mathrm{~K} & 6.7\end{array}$ & 3900 & $\begin{array}{lr}\text { Cl } & 394.8 \\
\mathrm{~K} & 26.0\end{array}$ \\
\hline \multirow[t]{3}{*}{ A. $\mathrm{S}$. } & $\mathrm{Na} 135.2$ & & $\mathrm{Na} \mathrm{350.0}$ & $\mathrm{Na} 141.0$ & & $\mathrm{Na} 493.6$ & Na 135.2 & & $\mathrm{Na} 457.1$ & $\mathrm{Na} 139.7$ & & $\mathrm{Na} 475.0$ \\
\hline & $\mathrm{Cl} \quad 97.2$ & 2585 & Cl 251.0 & $\mathrm{Cl} 100.4$ & 3500 & Cl 351.4 & $|\mathrm{Cl} 101.0|$ & 3380 & $\mathrm{Cl} \quad 341.4$ & $\mathrm{Cl} 102.2$ & 3400 & 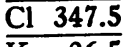 \\
\hline & & & K 16.1 & & & K 24.5 & & & & & & 26.5 \\
\hline \multirow[t]{3}{*}{ C. $\mathbf{N}$. } & $\mathrm{Na} 131.4$ & & $\mathrm{Na} 213.2$ & $\mid \mathrm{Na} 136.9$ & & $\mathrm{Na} 348.0$ & $\mathrm{Na} 134.2$ & & $\mathrm{Na} 295.3$ & $\mathrm{Na} 138.2$ & & $\mathrm{Na} 315.1$ \\
\hline & $\mathrm{Cl} \quad 95.0$ & 1620 & $\begin{array}{lll}\mathrm{Cl} & 154.0 \\
\end{array}$ & $\mathrm{Cl} 102.6$ & 2540 & $\overline{\mathrm{Cl}} 260.5$ & $\mid \mathrm{Cl} 99.8$ & 2200 & Cl 219.6 & Cl 104.4 & 2280 & Cl 238.0 \\
\hline & $\mathrm{K} \quad 5.0$ & & 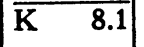 & & & $\begin{array}{ll}\mathrm{K} & 15.0\end{array}$ & 5.9 & & $\begin{array}{ll}\mathrm{K} & 12.9\end{array}$ & & & $\begin{array}{ll}\mathbf{K} \quad 15.0\end{array}$ \\
\hline \multirow[t]{3}{*}{ J. P. } & $\mathrm{Na} 133.5$ & & $\mathrm{Na} 318.8$ & $\mathrm{Na} 139.6$ & & $\mathrm{Na} 378.3$ & $\mathrm{Na} 128.7$ & & $\mathrm{Na} 358.0$ & & & \\
\hline & 96.4 & 2390 & $\overline{\mathrm{Cl}} \quad 230.1$ & $\left|\begin{array}{ll}\mathrm{Cl} & 103.6\end{array}\right|$ & 2710 & Cl 280.8 & $\left|\begin{array}{ll}\mathrm{Cl} & 102.2\end{array}\right|$ & 2780 & Cl 284.0 & & & \\
\hline & $\mathrm{K} \quad 4.4$ & & $\begin{array}{ll}\mathrm{K} & \mathbf{1 0 . 6}\end{array}$ & 5.2 & & $\begin{array}{ll}\mathbf{K} \quad 14.2 \\
\end{array}$ & 5.2 & & 14.6 & & & \\
\hline \multirow[t]{3}{*}{ P. W. } & $\mathrm{Na} 127.3$ & & $\mathrm{Na} 237.8$ & Na 139.3 & & $\mathrm{Na} 386.8$ & & & & & & \\
\hline & $\mathrm{Cl} \quad 90.6$ & 1865 & $\begin{array}{ll}\text { Cl } & 169.0 \\
\end{array}$ & $\mathrm{Cl} 103.8$ & 2770 & $\begin{array}{ll}\text { Cl } & 287.6 \\
\end{array}$ & & & & & & \\
\hline & 6.1 & & $\mathrm{~K} \quad 11.8$ & $\left|\begin{array}{ll}\mathrm{K} & \mathbf{5 . 0}\end{array}\right|$ & & K 14.0 & & & & & & \\
\hline \multirow[t]{3}{*}{ J. Z. } & $\mathrm{Na} 131.2$ & & $\mathrm{Na} 249.0$ & $\mathrm{Na} 138.7$ & & $\mathrm{Na} 320.6$ & & & & & & \\
\hline & 91.8 & 1900 & Cl 174.3 & $\mathrm{Cl} 96.8$ & 2330 & $\begin{array}{ll}\mathrm{Cl} & 225.5 \\
\end{array}$ & & & & & & \\
\hline & $\mathrm{K} \quad 6.1$ & & $\mathrm{~K} \quad 11.6$ & $\left|\begin{array}{ll}\mathrm{K} & 6.0\end{array}\right|$ & & 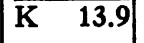 & & & & & & \\
\hline
\end{tabular}

who had been injected with the same preparation but in whom no untoward symptoms had been observed were found to have either slightly positive or negative intradermal tests.

\section{Plasma volume}

In a previous study (23) it was shown that an increase in plasma volume occurred in patients with Addison's disease following treatment with adrenal cortical extract. It is well known that a reduction in plasma volume with consequent hemoconcentration regularly accompanies a relapse.

Desoxy-corticosterone acetate treatment was associated with a marked increase in plasma volume (350 to $1,800 \mathrm{cc}$.) in all of the patients (Figure 2 and Table II). Withdrawal of treatment (48 hours or more) resulted in an appreciable reduction in plasma volume; resumption of treatment restored the plasma volume to normal. Changes in hematocrit corresponded closely to the changes in plasma volume.

Total blood volumes (Table III) were calculated from the plasma volumes and hematocrit determinations (19). Before treatment with desoxy-corticosterone acetate it was observed that the values for 5 of the patients were considerably lower than the values given by Gibson for normal individuals of the same surface area (24). Treatment with desoxy-corticosterone acetate resulted in a marked increase in the blood volume of these patients so that the values after treatment approximated normal. In one patient (F.M., 
TABLE III

The effect of desoxy-corticosterone acetate treatment on the total blood volume of patients with Addison's disease

\begin{tabular}{|c|c|c|c|c|c|c|c|c|}
\hline \multirow[b]{2}{*}{ Patient } & \multicolumn{4}{|c|}{$\begin{array}{l}\text { Previous to treatment with } \\
\text { desoxy-corticosterone } \\
\text { acetate }\end{array}$} & \multicolumn{4}{|c|}{$\begin{array}{l}\text { During treatment with } \\
\text { desoxy-corticosterone } \\
\text { acetate }\end{array}$} \\
\hline & $\begin{array}{c}\text { Surface } \\
\text { area }\end{array}$ & $\begin{array}{c}\text { Ex- } \\
\text { pected } \\
\text { blood } \\
\text { vol- } \\
\text { ume* }\end{array}$ & $\begin{array}{c}\text { Ac- } \\
\text { tual } \\
\text { blood } \\
\text { vol- } \\
\text { ume }\end{array}$ & $\begin{array}{c}\text { Per } \\
\text { cent } \\
\text { of } \\
\text { nor- } \\
\text { mal }\end{array}$ & $\begin{array}{c}\text { Surface } \\
\text { area }\end{array}$ & $\begin{array}{c}\text { Ex- } \\
\text { pected } \\
\text { blood } \\
\text { vol- } \\
\text { ume }\end{array}$ & $\begin{array}{c}\text { Ac- } \\
\text { tual } \\
\text { blood } \\
\text { vol- } \\
\text { ume }\end{array}$ & $\begin{array}{l}\text { Per } \\
\text { cent } \\
\text { of } \\
\text { nor- } \\
\text { mal }\end{array}$ \\
\hline & $\begin{array}{c}\text { square } \\
\text { meters } \\
1.72 \\
1.60 \\
1.68 \\
1.70 \\
1.61 \\
1.69 \\
1.49 \\
1.38\end{array}$ & $\begin{array}{c}c c . \\
5050 \\
4560 \\
4900 \\
5000 \\
4100 \\
4180 \\
4000 \\
3300\end{array}$ & \begin{tabular}{c|}
$c c$. \\
5200 \\
3740 \\
3880 \\
4310 \\
3180 \\
4210 \\
3600 \\
3460
\end{tabular} & $\begin{array}{r}103 \\
80 \\
75 \\
86 \\
75 \\
101 \\
90 \\
105\end{array}$ & $\begin{array}{c}\text { square } \\
\text { meters } \\
1.76 \\
1.67 \\
1.71 \\
1.73 \\
1.67 \\
1.70 \\
1.54 \\
1.44\end{array}$ & $\begin{array}{c}c c . \\
5200 \\
4850 \\
5000 \\
5100 \\
4150 \\
4200 \\
4300 \\
3700\end{array}$ & \begin{tabular}{c|}
$c c$. \\
5500 \\
4940 \\
5730 \\
5430 \\
3960 \\
4200 \\
4200 \\
3640
\end{tabular} & $\begin{array}{c}105 \\
102 \\
115 \dagger \\
107 \\
95 \\
100 \\
97 \\
98\end{array}$ \\
\hline
\end{tabular}

* Calculated by the method of Gibson for normal individuals of the same surface area.

$\uparrow$ Refer to text (Plasma volume).

Figure 2) it was apparent that the optimum dose of desoxy-corticosterone acetate had been exceeded since his total blood volume increased to 115 per cent of the calculated normal. With a reduction in the dose of desoxy-corticosterone acetate the blood volume has returned to approximately 100 per cent of the expected normal.

\section{Plasma electrolytes}

Severe adrenal insufficiency is usually associated with a marked reduction in the plasma concentration of sodium and chloride and an increase in the concentration of potassium $(9,10)$. It has been noted (23) that treatment with adrenal cortical extract may result in considerable improvement in the clinical condition of patients with Addison's disease before an increase in the plasma concentration of sodium and chloride may be detected. However, a considerable increase in the total plasma content of sodium and chloride may be demonstrated at this time as a result of the increase in plasma volume (23).

Desoxy-corticosterone acetate treatment resulted in a restoration of the plasma sodium and chloride concentration to normal levels in all of the patients (Table II). It is interesting to note that in 1 of the patients (E.V.) no increase in plasma concentration of sodium or chloride occurred during the first week of treatment al- though considerable clinical improvement was noted during this period (Figure 3). The total plasma content of sodium and chloride, however, was greatly increased as the result of increased plasma volume. In 1 patient a rise in the plasma concentration of sodium and chloride preceded a demonstrable increase in plasma volume. In this instance the total plasma content of sodium and chloride was increased as a result of the increased concentration of these ions. Improvement in the clinical condition of the patients was associated in every instance with an increase in the total plasma content of sodium and chloride whereas withdrawal of treatment and the subsequent development of signs of adrenal insufficiency were invariably associated with a reduction in the total plasma content of these ions.

Desoxy-corticosterone acetate treatment resulted in a reduction in the plasma concentration of potassium in those patients in whom the concentration of this ion was elevated. Changes in the total plasma content of potassium as a result of treatment with desoxy-corticosterone acetate were variable (Table II) inasmuch as the effect of the hormone in lowering the concentration of potassium was more than balanced by the increased plasma content resulting from the augmented plasma volume.

\section{Sodium and chloride balance}

It has been shown that in patients with Addison's disease, treatment with adrenal cortical extract results in a positive sodium and chloride balance (23). Withdrawal of adrenal cortical extract treatment is associated with a diuresis, an increased excretion of sodium and chloride and weight loss. Since in the absence of diarrhea or excessive sweating, approximately 95 per cent of ingested sodium and chloride is excreted in the urine, the renal excretion of these ions under these conditions may be used as a basis for calculating balance.

Treatment with desoxy-corticosterone acetate resulted in a marked retention of sodium in 7 of 8 patients (Figure 4, Table IV). Withdrawal of treatment resulted in a marked negative balance, and resumption of treatment resulted in sodium retention in all. Changes in chloride balance corresponded closely to the changes observed in sodium balance. 


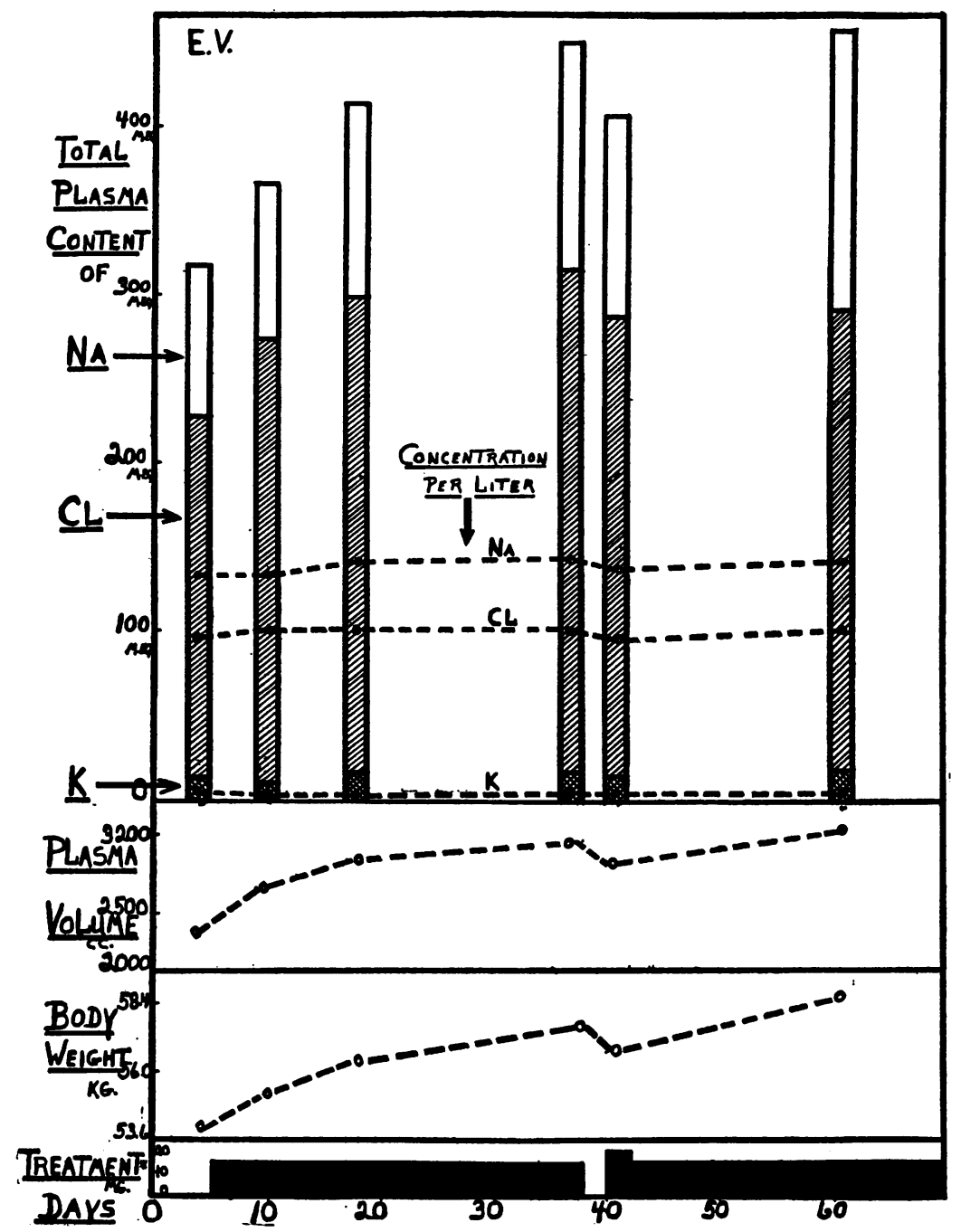

Fig. 3. The Effect of Desoxy-corticosterone Acetate Treatment on the Concentration and Total Quantity of Plasma Sodium, Chloride, and Potassium*

* Refers to a single daily intramuscular injection of desoxy-corticosterone acetate in sesame oil.

Renal excretion of potassium, inorganic phosphorus, and total nitrogen

In all of the patients, withdrawal of desoxycorticosterone acetate treatment was associated with a decreased renal excretion of potassium. This effect was similar to that observed in patients treated with adrenal cortical extract (23). The average reduction in excretion following desoxycorticosterone acetate treatment ranged from 4 to 20 m.eq. daily during the withdrawal period. Institution of desoxy-corticosterone acetate treatment resulted in a marked increase in the renal excretion of potassium during the first 2 to 4 days of treatment ( 7 patients). The average increase during this period ranged from 9 to 65 m.eq. per day. When desoxy-corticosterone acetate treatment was substituted for adequate adrenal cortical extract therapy no alteration in potassium excretion was noted.

Following desoxy-corticosterone acetate treatment changes in the excretion of inorganic phosphorus were similar to but not nearly so striking as the changes observed in potassium excretion. During the period of hormone withdrawal the 
TABLE IV

The effect of desoxy-corticosterone acetate treatment on sodium and chloride balance

\begin{tabular}{|c|c|c|c|c|}
\hline Patient & $\begin{array}{l}\text { Previous to } \\
\text { treatment }\end{array}$ & $\begin{array}{c}\text { During } \\
\text { treatment }\end{array}$ & $\left|\begin{array}{c}\text { Withdrawal } \\
\text { of } \\
\text { treatment }\end{array}\right|$ & $\begin{array}{c}\text { Treatment } \\
\text { restored }\end{array}$ \\
\hline \multirow[t]{2}{*}{ J. S. } & $\begin{array}{l}\text { m. eq. per day } \\
\mathrm{Na}+2.4\end{array}$ & $\begin{array}{c}\text { m. eq. per } \\
\text { day } \\
+75.3\end{array}$ & $\begin{array}{c}\text { m. eq. per } \\
\text { day } \\
-\quad 19.7\end{array}$ & $\begin{array}{c}\text { m. eq. per } \\
\text { day } \\
+38.9\end{array}$ \\
\hline & $\mathrm{Cl}+3.5$ & +60.9 & -1.0 & +23.7 \\
\hline \multirow[t]{2}{*}{ E. V. } & $\mathrm{Na}-123.8$ & +35.4 & -129.4 & +36.3 \\
\hline & $\mathrm{Cl}-128.8$ & +34.8 & -87.7 & +37.4 \\
\hline \multirow[t]{2}{*}{ F. M. } & $\mathrm{Na}-57.2$ & +47.9 & -70.6 & +39.5 \\
\hline & $\mathrm{Cl}-82.6$ & +5.7 & -97.7 & -4.3 \\
\hline \multirow[t]{2}{*}{ A. $S$. } & $\mathrm{Na}$ & +25.9 & -42.5 & +53.4 \\
\hline & $\mathrm{Cl}$ & +28.9 & -28.3 & +33.7 \\
\hline \multirow[t]{2}{*}{ C. N. } & $\mathrm{Na}-67.6$ & +91.4 & -112.2 & +48.8 \\
\hline & $\mathrm{Cl}-72.8$ & +92.0 & -99.0 & +44.2 \\
\hline \multirow[t]{2}{*}{ J. P. } & $\mathrm{Na}-17.3$ & +77.2 & -7.6 & +37.8 \\
\hline & $\mathrm{Cl}-32.8$ & +70.8 & -26.0 & +42.8 \\
\hline \multirow[t]{2}{*}{ P. W. } & $\mathrm{Na}-50.3$ & +63.4 & & \\
\hline & $\mathrm{Cl}-57.0$ & +37.6 & & \\
\hline \multirow[t]{2}{*}{ J. Z. } & $\mathrm{Na}$ & -2.3 & -63.1 & +9.8 \\
\hline & $\mathrm{Cl}$ & -5.0 & -48.0 & +2.8 \\
\hline
\end{tabular}

average decrease in inorganic phosphorus excretion ranged from 50 to $300 \mathrm{mgm}$. per day ( $6 \mathrm{pa}-$ tients). During the first 4 days of treatment following a withdrawal period, an increased excretion of from 60 to $300 \mathrm{mgm}$. daily of inorganic phosphorus was noted ( 7 patients).

Changes in the renal excretion of total nitrogen following desoxy-corticosterone acetate treatment were neither striking nor consistent.

\section{Carbohydrate metabolism}

The difficulty in obtaining satisfactory data (glucose tolerance test, insulin sensitivity, epinephrine response, and respiratory quotients) during the untreated control periods of patients with Addison's disease has hindered thus far any careful study of the effect of desoxy-corticosterone treatment on carbohydrate metabolism. Blood sugar determinations in the fasting state ( $8 \mathrm{pa}$ tients) preceding treatment with desoxy-corticos- terone acetate averaged $79 \mathrm{mgm}$. per cent ( 73 to $88 \mathrm{mgm}$. per cent); during the initial period of treatment with desoxy-corticosterone acetate an average value of $77 \mathrm{mgm}$. per cent (58 to $88 \mathrm{mgm}$. per cent) was observed; during a period of treatment ( 6 patients) the average value was $79 \mathrm{mgm}$. per cent (64 to $92 \mathrm{mgm}$. per cent) ; following the resumption of treatment (4 patients) the average blood sugar level was found to be $79 \mathrm{mgm}$. per cent (63 to $96 \mathrm{mgm}$. per cent).

In 2 of the patients (J.Z. and C.N.) the administration of 1.75 grams of glucose per $\mathrm{kgm}$. of body weight was followed by a flat blood sugar curve although the patients at that time appeared to be in good condition.

The blood sugar values following the administration of glucose orally to bilaterally adrenalectomized dogs treated with desoxy-corticosterone acetate and maintained on a diet of low sodium and chloride content were not significantly differerent from the values obtained in normal dogs maintained on a similar diet (25).

\section{Blood nonprotein nitrogen}

In adrenalectomized dogs the nonprotein nitrogen level of the blood is a sensitive indicator of a change in the animal's condition. In patients with Addison's disease, unless complicated by a renal lesion, a significant rise in blood nonprotein nitrogen is rarely observed unless accompanied by rather marked dehydration.

In the 8 patients studied in this report, the average blood level of nonprotein nitrogen upon instituting desoxy-corticosterone acetate treatment was found to be $34 \mathrm{mgm}$. per cent (29 to $40 \mathrm{mgm}$. per cent.). Treatment with desoxy-corticosterone acetate resulted in no significant change.

\section{Pigmentation}

Except for the changes in color which resulted from increased hydration no alteration in pigmentation has as yet been observed in any of the patients following treatment with desoxy-corticosterone acetate ( 2 to 5 months).

\section{Dosage and mode of administration}

The desoxy-corticosterone acetate used in these studies was prepared in oil of sesame, $5 \mathrm{mgm}$. of the compound being contained in $1 \mathrm{cc}$. of oil. In- 


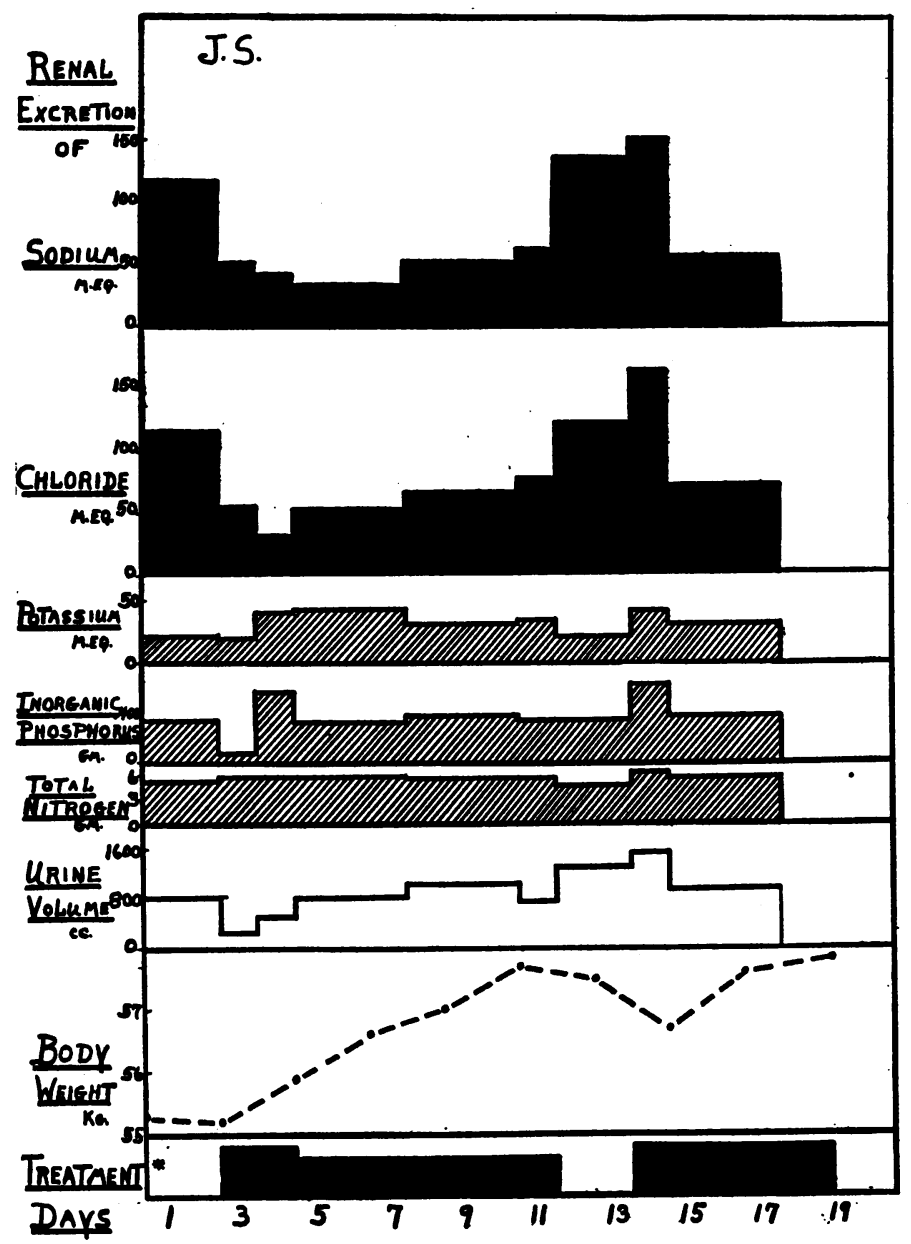

Fig. 4. The Effect of Desoxy-corticosterone Acetate Treatment on the Renal Excretion of Electrolytes in a PatIENT WITH AdDison's Disease*

jections were made subcutaneously or intramuscularly and usually once daily, since animal experiments (8) indicated that the material in oil solution has a prolonged action ( 24 hours). In most patients a single daily injection of 2 to $10 \mathrm{mgm}$. daily was sufficient for maintenance when added sodium chloride therapy was employed. The withdrawal of sodium chloride therapy (10 to 20 grams of $\mathrm{NaCl}$ daily) increases the requirement of desoxy-corticosterone by approximately 10

* Refers to a single daily intramuscular injection of desoxy-corticosterone acetate in sesame oil. During this study the patient was provided with a constant diet which was found to contain, by analysis, 123.8 m.eq. of sodium, 123.8 m.eq. of chloride, 55.4 m.eq. of potassium, 1.24 grams of total phosphorus, and 7.37 grams of total nitrogen. mgm. daily. A quantity as great as 30 to $35 \mathrm{mgm}$. daily has been injected intramuscularly with no untoward effect.

The continued daily injection of more than 3 cc. of sesame oil was attended by the development of fever, tachycardia, and malaise in 2 patients. The withdrawal of treatment resulted in a prompt disappearance of these signs and symptoms. It was shown that in these patients this untoward reaction was due to the injection of sesame oil since the intradermal injection of oil alone resulted in a very marked, positive skin reaction and in 1 patient in a febrile response and since the subcutaneous implantation of $200 \mathrm{mgm}$. of crystalline desoxy-corticosterone acetate was associated with no systemic or local reaction. In these 2 pa- 
tients it was possible at a later date to maintain them successfully on injections of the same preparation of desoxy-corticosterone acetate in oil by resuming treatment with very small intramuscular injections and slowly increasing the daily dose. It is also possible to prepare desoxy-corticosterone acetate in a solution of peanut oil.

The prolonged action of the compound following its intramuscular injection permits effective therapy with a single daily injection. It should be noted that in the crisis of adrenal insufficiency immediate treatment with intravenous sodium chloride and glucose solution, and an aqueous preparation of adrenal cortical extract should accompany intramuscular injections of desoxy-corticosterone acetate in oil since several hours may be required for the absorption of the latter.

Studies thus far indicate that in both adrenalectomized dogs and patients with Addison's disease $1 \mathrm{mgm}$. of a solution of desoxy-corticosterone acetate in oil is equivalent in effect to approximately $3 \mathrm{cc}$. of a potent commercial adrenal cortical extract, ${ }^{4}$ under conditions in which the desoxy-corticosterone acetate in oil is administered as a single daily intramuscular injection and the adrenal cortical extract is given subcutaneously in divided doses throughout the day.

\section{DISCUSSION}

It appears that in its effect on patients with Addison's disease, desoxy-corticosterone acetate treatment simulates qualitatively the action of adrenal cortical extracts. These observations confirm those of Levy-Simpson (26). The potency of desoxy-corticosterone acetate, the constancy and uniformity of the preparation, and the prolonged period of action following a single injection contribute greatly to the success which has attended its use.

The increase in body weight and the elevation of blood pressure following continued treatment with this compound have been uniformly consistent and striking. Another pronounced effect of treatment is a rapid restoration of plasma volume to normal. Determinations of the sodium and chloride concentration of the plasma demonstrate

4 The authors wish to acknowledge the generous supply of Wilson adrenal cortical extract which was provided for this study by Doctor David Klein, Wilson Laboratories, Chicago, Illinois. that frequently the concentration of these ions does not correlate with the clinical condition of the patient. It appears that in all patients adequately treated one may expect a restoration of the plasma concentration of electrolytes to normal. However, during the development of the signs and symptoms of adrenal insufficiency and during the early period of treatment, one may observe little or no correlation between the plasma concentration of sodium and chloride and the clinical state of the patient, but the plasma volume and the total plasma content of sodium and chloride follow closely the changes observed in the condition of the patient.

Because of the very marked sodium and chloride retaining effect which follows treatment with desoxy-corticosterone acetate it is possible to produce edema in patients given an excess of hormone and sodium chloride therapy. Reduction of either the sodium chloride intake or the quantity of desoxy-corticosterone acetate results in a prompt diuresis and a disappearance of edema.

Patients with Addison's disease in whom active tuberculosis exists (J.Z. and A.S.) present an added problem. Because of the marked improvement in the general clinical condition of these patients as a result of treatment with desoxy-corticosterone acetate, an attempt is being made to improve the tuberculous lesion by means of sanatorium care.

The close chemical relationship which exists between desoxy-corticosterone (21-hydroxyprogesterone) and progesterone suggests that a sex hormone effect might possibly be induced by injections of large quantities of desoxy-corticosterone acetate. Thus far, however, changes in the breasts or in the menstrual cycle have not been observed in 3 female patients treated with daily injections ( 2 to $20 \mathrm{mgm}$. daily) of desoxy-corticosterone acetate. It is of interest that in earlier studies it was shown (26) that injections of crystalline progesterone exerted an effect in normal and adrenalectomized dogs which was qualitatively similar to that which occurred following injections of adrenal cortical extracts. The marked " cortinlike" effect which desoxy-corticosterone (21-hydroxyprogesterone) possesses indicates again the close relationship which exists between the hormones of the adrenal cortex and the corpus luteum.

It can not be stated from these studies that 
desoxy-corticosterone acetate exerts any specific effect upon carbohydrate metabolism. If the disorder of carbohydrate metabolism in adrenal insufficiency is dependent upon altered sodium, chloride, and potassium metabolism (28) one might expect the disorder to be corrected by desoxy-corticosterone acetate therapy since sodium, chloride, and potassium metabolism are apparently restored to normal. In patients in whom adrenal medullary destruction accompanies cortical deficiency, one would not expect desoxycorticosterone acetate treatment to alter any change in carbohydrate metabolism which resulted from a deficit of epinephrine secretion. Until more definite information is obtained, it seems highly desirable to include in the treatment of all patients with Addison's disease a diet high in readily available carbohydrate. There appears to be no indication for reducing the potassium content of the diet of patients adequately treated with desoxy-corticosterone acetate.

One of the remarkable changes which successful treatment introduces is the potentiality of having patients develop rather acutely the signs of adrenal insufficiency when therapy is discontinued suddenly even for as short a period as 72 hours. This effect has also been observed in patients following the sudden withdrawal of adequate quantities of adrenal cortical extract or sodium chloride therapy. The sudden withdrawal of adequate treatment results in a marked diuresis, an increase in the renal excretion of sodium and chloride, potassium retention, a decrease in plasma volume, and a decrease in the total plasma content of sodium and chloride. Within 72 hours after the withdrawal of treatment, signs and symptoms of acute adrenal insufficiency may appear. In this respect an adequately treated patient responds to the sudden withdrawal of treatment in a manner very similar to the response of normal animals to bilateral adrenalectomy. Although experimental evidence (29) indicates that atrophy of the adrenal cortex may follow intensive hormone therapy in normal animals, it is not likely that this is of clinical significance since well developed symptoms of Addison's disease rarely occur until extensive destruction of adrenal cortical tissue is present. At present it would seem entirely unjustifiable to withhold substitution therapy from a patient with Addison's disease, in whom the administration of sodium salts or a diet of low potassium content did not permit the resumption of normal activity.

Although the effect of treatment with this hormone has been uniformly striking in all of the patients, it is realized that the period of treatment in many instances is too short to do other than demonstrate the nature of the changes produced. In all of the patients, the effect of desoxy-corticosterone acetate treatment was observed during at least 1 period in which no sodium chloride therapy was added, and in 5 patients (E.V., C.N., A.S., F.M., and J.S.) an attempt is being made to maintain these patients over long periods of time with no treatment other than desoxy-corticosterone acetate alone.

\section{SUMMARY}

Intramuscular injections of a solution of synthetically prepared desoxy-corticosterone actetate in oil ( 2 to $30 \mathrm{mgm}$. daily) resulted in marked improvement in the clinical condition of 8 patients with Addison's disease during a period in which added sodium chloride therapy was withheld. The changes associated with desoxy-corticosterone acetate treatment were: $(a)$ increase in body weight, (b) elevation of blood pressure, $(c)$ increase in plasma volume, $(d)$ restoration of plasma concentration of sodium, chloride, and potassium to normal levels, $(e)$ positive sodium and chloride balance, $(f)$ increased renal excretion of potassium and inorganic phosphorus, $(g)$ improved muscular strength and sense of well-being.

Withdrawal of desoxy-corticosterone acetate treatment (48 to 72 hours) resulted in (a) weight loss, (b) decrease in plasma volume, $(c)$ decrease in total plasma content of sodium and chloride, $(d)$ a negative sodium and chloride balance, $(e)$ retention of potassium and inorganic phosphorus, ( $f$ ) muscular weakness, $(g)$ loss of appetite, and $(h)$ the appearance of symptoms of adrenal insufficiency. Resumption of treatment again resulted in marked improvement and in the specific changes noted above.

\section{CONCLUSIONS}

Intramuscular injections of synthetically prepared desoxy-corticosterone acetate appear to reproduce in patients with Addison's disease all of the known effects of treatment with potent adrenal cortical extracts. It is possible to maintain 
patients with Addison's disease in excellent condition by means of this treatment without added sodium chloride therapy.

The authors are indebted to Miss Mildred Caldwell, Supervisor of the Metabolism Ward, Miss Elizabeth Olsen, Dietician-in-charge of the Metabolism Ward, Mrs. Florence White of the Biochemical Laboratory of the Johns Hopkins Hospital, Harry Eisenberg, Kay Eisenberg, and William Sause of the Chemical Division of the Department of Medicine, Johns Hopkins Medical School for their technical assistance and continued cooperation.

\section{PROTOCOLS OF PATIENTS}

J. Z. (Number 155645), a 19-year-old ltalian boy, was admitted to the Johns Hopkins Hospital on October 27, 1938 with a diagnosis of Addison's disease. His illness began in the spring of 1936 with the gradual onset of loss of strength, appetite and weight, and a slowly progressive generalized brown pigmentation of the skin. In September 1936 he began to have persistent vomiting. At this time a diagnosis of Addison's disease was made and treatment with sodium chloride and adrenal cortical extract was begun. He improved promptly and since that time has been maintained in fair health on a high sodium chloride intake and 1 to $2 \mathrm{cc}$. of adrenal cortical extract $^{5}$ ( 40 to 80 grams fresh adrenal cortex) daily, injected subcutaneously. On several occasions during the past 2 years he has required intravenous saline, and has continued to be markedly underweight. In 1937 tubercle bacilli were found in his urine. During his illness the patient had lost 25 pounds in weight.

In 1928 the patient's brother died of tuberculosis and in 1930 his mother died of the same disease. Another brother and sister were sent to a preventorium in 1933 as tuberculosis suspects, although the disease was never proved in these siblings.

Physical examination on admission, October 27, 1938, revealed a thin, poorly nourished and underdeveloped white boy, appearing weak and tired. His temperature was $99.4^{\circ} \mathrm{F}$., pulse rate 88 per minute, respirations 18 per minute, and blood pressure $90 / 50 \mathrm{~mm}$. $\mathrm{Hg}$. The skin was dry and pale, and there was generalized diffuse brownish pigmentation over the neck, trunk and extremities becoming almost black over the knees, thighs, and gluteal folds. Small cervical and axillary lymph nodes were palpable but there was no general glandular enlargement. The lungs were clear and the heart normal.

The laboratory data on admission were as follows: hemoglobin 48 per cent (11.5 grams), red blood cells, 3.69 million, hematocrit 34 per cent cells, white blood cells 4,760 with polymorphonuclears 68 per cent, lymphocytes 22 per cent, monocytes 10 per cent. The sedimentation rate was $25 \mathrm{~mm}$. in 1 hour, corrected. The blood Wassermann was negative. The blood nonprotein nitrogen was $40 \mathrm{mgm}$. per cent and blood sugar $70 \mathrm{mgm}$. per cent. The serum $\mathrm{CO}_{2}$ combining power was 43.8 volumes per cent, the serum concentration of sodium $131.2 \mathrm{~m} . e q$.,

5 Wilson and Company adrenal cortical extract. chloride 91.8 m.eq., and potassium 6.08 m.eq. per liter. The total serum protein was 7.2 grams.

The urine was found to have a specific gravity of 1.020 and contained a trace of albumin and many leukocytes but no red cells or casts. Acid fast bacilli were obtained from urine specimens both by culture and guinea pig inoculation.

An $x$-ray of the chest showed inactive fibroid infiltration in the left apex. In a flat plate of the abdomen, calcium shadows were visible in both suprarenal regions, and stereoscopic $x$-rays of the skull showed numerous calcium shadows scattered throughout the brain which were interpreted as being healed tubercles.

The basal metabolic rate was plus 18 per cent. On December 17, a phenolsulphonthalein test showed a dye excretion of 30 per cent in 30 minutes and 52 per cent at the end of 2 hours. An electrocardiogram gave a normal tracing.

Résumé of treatment with desoxy-corticosterone acetate. Because of the presence of an active tuberculous lesion of the urinary tract and the very poor clinical condition of the patient 15 grams of added sodium chloride were continued during the institution of desoxycorticosterone acetate treatment ( 20 to $30 \mathrm{mgm}$. daily). This treatment resulted in marked improvement in the patient's general condition, increased appetite and sense of well-being, marked increase in weight, and increased blood pressure. Two weeks after desoxy-corticosterone acetate treatment had been instituted, the added sodium chloride was entirely discontinued, the patient's progress being maintained successfully by means of desoxycorticosterone acetate treatment alone. Subsequently, withdrawal of desoxy-corticosterone acetate treatment resulted in a rapid onset of the symptoms of adrenal insufficiency. At this time resumption of desoxycorticosterone acetate treatment without added sodium chloride resulted in marked improvement in the patient's clinical condition. (Data are given in the corresponding charts and tables of the text.)

After being maintained successfully for 20 days by means of desoxy-corticosterone acetate treatment alone (25 to 30 mgm. daily) an attempt was made to determine the requirement of hormone when sodium chloride treatment was added (sodium chloride therapy alone had never been sufficient to maintain this patient). It was found that a single daily injection of $5 \mathrm{mgm}$. of desoxy-corticosterone acetate daily was sufficient for this patient when 15 grams of sodium chloride were added to his diet. At present he is being treated successfully by this means and an attempt is being made to treat the active tuberculous lesion in the genito-urinary tract.

A. S. (Number 151599), a 32-year-old white male bookkeeper, was admitted to the Johns Hopkins Hospital September 12, 1938, complaining of weakness, nausea, and vomiting. The patient dated his present illness from October 1935 when he fractured 3 lumbar vertebrae as the result of a fall. He was hospitalized for 6 weeks at that time and never regained his strength completely. In December 1935, his right wrist became swollen and 
painful and has continued to be stiff ever since. In January 1936 he had an attack of pleurisy with pain in the right chest, night sweats, and fever lasting 11 days. Thereafter he continued to feel weak; he tired easily, and his appetite was markedly decreased. In July 1936 he developed epididymitis on the right side which required incision and drainage. A draining sinus has persisted ever since. Six months before admission he began to lose weight. Weakness and exertional dyspnea became more marked, and he noticed dizziness on bending over and had frequent attacks of nausea and vomiting. During this period a progressive deepening in the color of the skin of his face, neck, and arms became apparent. He lost $13.6 \mathrm{kgm}$. in the course of his illness.

Physical examination on September 12, 1938 revealed a thin man, appearing tired and weak. His temperature was $99.8^{\circ} \mathrm{F}$., pulse 96 per minute, respirations 16 per minute and blood pressure $100 / 64 \mathrm{~mm}$. $\mathrm{Hg}$. There was diffuse light brownish pigmentation of the skin of the face, neck, arms, hands, nipples, and genitalia with splotchy pigmentation over the back and hips. Some pigmentation was noted just inside the lip margins. Coarse bronchial râles were heard scattered throughout both lungs but there was no change in resonance or breath sounds. The heart was normal, and the abdomen negative. The right epididymis was enlarged, firm and slightly tender, and 2 scars were present on the scrotum from both of which drained a small amount of serous discharge. The prostate was moderately enlarged, tender, and indurated. The right wrist was stiff and painful on motion or pressure.

The laboratory data on admission were as follows: The red blood cells were 4.96 million, hemoglobin 94 per cent (13.7 grams), white blood cells 10,320 with 51 per cent polymorphonuclears, 39 per cent lymphocytes, 3 per cent monocytes, 6 per cent eosinophils, and 1 per cent basophils. The volume of packed red cells was 43 per cent. The blood Wassermann was negative. The blood nonprotein nitrogen was $40 \mathrm{mgm}$. per cent, blood sugar 75 mgm. per cent, plasma $\mathrm{CO}_{2}$ combining power 39.3 volumes per cent, and total plasma protein 7.06 grams per cent. The serum concentration of sodium was 122.5 m.eq. per liter and of chloride 88.6 m.eq. per liter.

The urine examination revealed a specific gravity of 1.010 , a trace of albumin, and no sugar. Microscopic examination showed 3 to 5 red blood cells and 50 to 60 white blood cells per high power field and an occasional hyalin cast. Acid-fast organisms were recovered from the urine on culture and guinea pig inoculation. An electrocardiographic tracing was normal.

$\mathrm{X}$-rays revealed fibroid infiltration of both apices due to quiescent tuberculosis, no adrenal calcification, and a destructive arthritis of the right wrist. The basal metabolic rate was +1 per cent. A phenolsulphonphthalein test showed 25 per cent excretion of the dye in one-half hour and 50 per cent in 2 hours. The tuberculin test was negative in dilutions up to $1: 10,000$.

In an attempt to establish the diagnosis of Addison's disease the patient was placed on a constant diet and after a 3-day control period the sodium and chloride balance was studied during the injection of adrenal cortical extract (8 cc. which contained the equivalent of 400 grams of fresh gland) administered daily for 3 days in divided doses subcutaneously. During the period on extract there was a definite retention of sodium and chloride which was followed by a marked loss when extract was discontinued.

The patient was then placed on a high sodium chloride intake and $2 \mathrm{cc}$. of adrenal cortical extract ${ }^{\circ}$ (100 grams of fresh gland) were administered subcutaneously each day. On this regimen he gained weight, his appetite increased, nausea disappeared, and the blood electrolytes returned to normal values.

It was felt that the diagnosis of Addison's disease was definite and that, in addition, the patient had tuberculosis of the prostate and epididymis and an old tuberculous arthritis of the right wrist. On November 15,1938 , this patient was readmitted for trial of desoxycorticosterone acetate therapy.

Résumé of treatment with desoxy-corticosterone acetate. Blood examination on admission revealed the following values: serum sodium 139.3 m.eq., serum chloride 99.4 m.eq. and serum potassium 7.08 m.eq. per liter, carbon dioxide combining power 54.1 volumes per cent, nonprotein nitrogen $31 \mathrm{mgm}$. per cent, sugar $78 \mathrm{mgm}$. per cent, hematocrit 40.0 per cent cells, and total protein 6.68 grams per cent. Desoxy-corticosterone acetate treatment (20 mgm. daily) was substituted for the combined sodium chloride and extract treatment. The patient felt well, gained weight, and showed a striking gain in plasma volume. Withdrawal of desoxy-corticosterone acetate treatment resulted in weight loss, decreased appetite, hemoconcentration, a lowering of the serum concentration of sodium and chloride, a marked diuresis, and increased renal excretion of sodium and chloride. Again, treatment with desoxy-corticosterone acetate (20 mgm. daily) without added sodium chloride or extract therapy resulted in marked gain in weight and improved clinical status. (Data are given in the corresponding charts and tables in the text.) At present this patient has been maintained in good condition for more than 4 months by means of a single daily injection of $10 \mathrm{mgm}$. of desoxy-corticosterone acetate without added sodium chloride therapy. An attempt is now being made to treat this patient's urogenital tuberculosis, since his general condition otherwise is compatible with his resuming work as a bookkeeper.

F. M. (Number 144800), a 32-year-old truck driver, was first admitted to the Johns Hopkins Hospital on August 13, 1938, complaining of weakness, nausea, and pigmentation of the skin. His present illness began in March 1936, 21/2 years previously, when, following a severe sore throat, he began to notice dizziness, weakness, and nausea. He had an attack of persistent vomiting lasting a week and was told by his doctor that his blood pressure was low. For 3 months he was unable to work but then improved sufficiently to return to his duties as

6 Wilson and Company adrenal cortical extract. 
truck driver. However, he never fully regained his strength and continued to have attacks of nausea and vomiting at irregular intervals lasting 7 to 10 days. During his illness he lost $6.8 \mathrm{kgm}$. in weight. In the summer of 1936 he was troubled with cramps in his legs and some diarrhea. During the 6 months prior to admission he noticed increased brown pigmentation of his face, neck, and forearms.

Physical examination on admission, August 13, 1938, revealed a well developed, fairly well nourished white male appearing rather quiet and listless but not acutely ill. The temperature was $99.8^{\circ} \mathrm{F}$., pulse rate 64 per minute, respirations 20 per minute, blood pressure $90 / 60$ $\mathrm{mm}$. $\mathrm{Hg}$, and weight $64.1 \mathrm{kgm}$. There was generalized brownish pigmentation, especially of exposed parts, perineal region, and scars. There were several dark nevi on the face and a small pigmented area on the buccal mucosa. The heart and lungs were normal.

The laboratory data revealed the following: Red blood cells 3.55 million, hemoglobin 73 per cent (10.7 grams), white blood cells 5,440 , polymorphonuclears 42 per cent, lymphocytes 52 per cent, eosinophils 2 per cent, basophils 4 per cent, volume of packed red blood cells 32 per cent. The blood Wassermann reaction was negative. The blood nonprotein nitrogen was $44 \mathrm{mgm}$. per cent, blood sugar $77 \mathrm{mgm}$. per cent, serum concentration of sodium 132.1 m.eq., and of chloride 98.4 m.éq. per liter, plasma carbon dioxide combining power 45.8 volumes per cent, total protein 6.6 grams per cent, serum cholesterol 244 mgm. per cent, serum calcium $11.2 \mathrm{mgm}$. per cent, and phosphorus $4.9 \mathrm{mgm}$. per cent.

The urine showed a specific gravity of 1.020. No albumin or sugar was present. On microscopic examination occasional white blood cells and hyalin casts were observed.

The phenolsulphonthalein test showed an excretion of 15 per cent in 30 minutes and 65 per cent in 2 hours. The basal metabolic rate varied between -12 and -23 per cent. X-rays of the chest were clear; no calcification of the adrenals was noted; the sinuses showed clouding of the left antrum. The tuberculin test was positive $(1: 1,000)$.

Course. Following admission the patient was provided with a constant diet to which was added 15 grams of sodium chloride. The patient showed a positive sodium and chloride balance during a 3-day period in which $4 \mathrm{cc}$. of adrenal cortical extract were injected twice daily. A negative sodium and chloride balance was noted preceding and following the period of treatment. Following these observations a high sodium chloride intake was maintained and the patient showed a steady gain in weight and improvement in appetite during his 3 weeks in the hospital. At the time of discharge, September 3, 1938, the serum concentration of sodium was 139.9 m.eq. and chloride 102.0 m.eq. per liter. The blood nonprotein nitrogen was $32 \mathrm{mgm}$. per cent, plasma carbon dioxide combining power 56.9 volumes per cent, blood pressure $100 / 70 \mathrm{~mm} . \mathrm{Hg}$, and body weight $65.9 \mathrm{kgm}$.

Following discharge from hospital he continued to take
15 grams of sodium chloride daily and felt stronger than before admission but he was still unable to carry on his work as truck driver. On October 18, 1938, he was readmitted for trial of desoxy-corticosterone acetate therapy.

Résumé of treatment with desoxy-corticosterone acetate. Blood examination on admission revealed the following values: serum sodium 136.0 m.eq., serum chloride 96.6 m.eq., and serum potassium 6.72 m.eq. per liter, carbon dioxide combining power 47.5 volumes per cent, nonprotein nitrogen $38 \mathrm{mgm}$. per cent, sugar $73 \mathrm{mgm}$. per cent, hematocrit 46.3 per cent cells, and total protein 6.53 grams per cent. Desoxy-corticosterone acetate treatment (15 mgm. daily for 9 days) resulted in marked improvement in his muscular strength, appetite, and sense of well-being. Withdrawal of desoxy-corticosterone acetate treatment ( 3 days) resulted in weight loss, some loss of strength and appetite, a marked increase in the renal excretion of sodium, and a rise in the serum concentration of potassium. Resumption of desoxy-corticosterone acetate treatment at this time resulted in marked improvement accompanied by a gain in weight and strength and an increase in blood pressure. (Data are given in the corresponding charts and tables of the text.) At no time during these studies was added sodium chloride given. At present, this patient is working at his occupation as truck driver, his treatment consisting of $10 \mathrm{mgm}$. of desoxy-corticosterone acetate daily without added sodium chloride therapy.

$C$. $N$. (Number 100114), a married, female telephone operator, 34 years of age, was admitted to the Johns Hopkins Hospital on June 3,1936, complaining of weakness, weight loss, nausea, and vomiting. Three years before admission the patient had noticed increasing fatigue and some darkening of her skin. For two weeks before admission nausea had been present almost constantly and the patient had been confined to bed. During her illness she had lost $15.9 \mathrm{kgm}$. in weight. Until the present illness her menses had been normal. For one year prior to admission her menses had been irregular. In 1932 and again in 1933 she had had a peritonsillar abscess.

Physical examination on admission June 2, 1936, revealed a pale woman who appeared to be rather weak and showed evidence of considerable weight loss. Her temperature was $97.2^{\circ} \mathrm{F}$., pulse rate 82 , respirations 20 , and blood pressure $86 / 60 \mathrm{~mm}$. Hg. Her skin was slightly tanned. There was dark pigmentation of the borders of the lips and a large blotchy brown area over the lower left abdomen. The heart sounds were distant and of poor quality, and the radial pulses were feeble. The physical examination was otherwise normal.

The laboratory findings were as follows: Hemoglobin 106 per cent, red blood cells 5.3 million (hemoconcentration), white blood cells 12,750 , polymorphonuclears 64 per cent, lymphocytes 26 per cent, monocytes 8 per cent, eosinophils 2 per cent, basophils 1 per cent, cell volume 48 per cent, blood Wassermann test negative, nonprotein nitrogen $46 \mathrm{mgm}$. per cent, sugar $80 \mathrm{mgm}$. per cent, plasma sodium concentration 138.9 m.eq. per liter, and 
the basal metabolic rate -11 per cent. The urine was normal.

A trial of salt deprivation was begun, and in 3 days a typical Addisonian crisis occurred. Plasma sodium concentration fell from a level of 138.9 m.eq. to 124 m.eq. per liter; and the patient became semicomatose, the blood pressure being $66 / 44 \mathrm{~mm} . \mathrm{Hg}$. Rapid recovery followed the administration of cortical extract and the intravenous infusion of sodium chloride and glucose. The patient was discharged on June 20,1936, feeling somewhat weak but otherwise improved.

During the next year the patient continued to be in fair health although she was never strong enough to do her housework. On August 28, 1937, she was admitted to the hospital in a severe crisis. Following large amounts of salt and glucose by vein and extract by vein and subcutaneously, she improved rapidly and remained well on injected extract and a high salt (10 to 12 grams of $\mathrm{NaCl}$ daily) and carbohydrate intake.

Since September 18,1937 , orally administered ${ }^{7}$ extract had been substituted for injections of extract. Her health continued to improve, and 5 months later she was able to return to her former work on a part-time basis in addition to doing her own housework and gardening. On October 17, 1938, she was readmitted for trial of desoxycorticosterone acetate therapy.

Résumé of treatment with desoxy-corticosterone acetate. On admission, blood examination revealed the following values: serum sodium 131.4 m.eq., serum chloride 95.0 m.eq. and serum potassium 5.00 m.eq. per liter, carbon dioxide combining power 56.0 volumes per cent, nonprotein nitrogen $40 \mathrm{mgm}$. per cent, sugar $78 \mathrm{mgm}$. per cent, and total protein 6.88 grams per cent. Desoxycorticosterone acetate (10 to $15 \mathrm{mgm}$. daily) was substituted for the orally administered extract, the sodium chloride therapy being continued. The substitution of desoxy-corticosterone acetate treatment (sodium chloride 15 grams daily being continued) resulted in marked clinical improvement, an increase in blood pressure, a very marked retention of sodium and chloride and a striking gain in weight. On the 7 th day of treatment as a result of the marked retention of sodium, moderate edema of the face and extremities was apparent. Withdrawal of desoxy-corticosterone acetate treatment (sodium chloride 15 grams daily being continued) resulted in a marked diuresis, marked weight loss, and after 72 hours in loss of appetite and strength. Resumption of desoxycorticosterone acetate treatment (5 to $10 \mathrm{mgm}$. daily) resulted in prompt improvement and again was accompanied by a marked gain in weight. At this time the added sodium chloride therapy (15 grams daily) was entirely discontinued and the patient was treated with desoxy-corticosterone acetate (5 mgm. daily) only. (Data are given in the corresponding charts and tables of the text.)

This patient has now been maintained in good condition for 5 months by means of desoxy-corticosterone

7 Wilson and Company adrenal cortical extract added to glycerol. acetate treatment ( 2 to $5 \mathrm{mgm}$. daily) without added sodium chloride therapy. On this regimen she has been capable of carrying on her duties as housewife. Furthermore, the patient states that she feels better now than she has in several years.

J. S. (Number 155073), a 29-year-old telegraph clerk, was admitted to the Johns Hopkins Hospital on October 21, 1938, complaining of nausea, vomiting, and gaseous distention. The present illness began in 1934 with gradual onset of abdominal distention and discomfort chiefly after meals. At the same time dizziness on arising was noted. In 1936 he first noticed some brownish pigmentation on his nose and upper lip which increased only slightly during the subsequent two years. During his illness his weight decreased from $72.7 \mathrm{kgm}$. to 56.8 $\mathrm{kgm}$. In 1936 he was told his blood pressure was $90 \mathrm{~mm}$. $\mathrm{Hg}$ systolic, but during the year prior to admission it was found to be $110 \mathrm{~mm}$. $\mathrm{Hg}$.

Physical examination on October 21, 1938, revealed a tall, thin, asthenic white male, slow of speech and movement, and appearing weak and emaciated, but not acutely ill. The temperature was $99^{\circ} \mathrm{F}$., pulse rate 88 per minute, respirations 22 per minute, and blood pressure $115 / 70 \mathrm{~mm} . \mathrm{Hg}$ with the patient in a recumbent position, $90 / 60 \mathrm{~mm}$. $\mathrm{Hg}$ with the patient in an upright position. There was widespread brownish pigmentation, particularly of the finger joints, genitalia, and buttocks. There were several dark nevi on the thorax. The lungs were clear and the heart sounds were normal.

The laboratory data were as follows: Hemoglobin was 104 per cent (15.1 grams), red blood cells 5.19 million, white blood cells 5,350 with polymorphonuclears 71 per cent, lymphocytes 24 per cent, monocytes 4 per cent, and eosinophils 1 per cent. The hematocrit was 47 per cent cells. The blood Wasserman was negative. The blood nonprotein nitrogen was $32 \mathrm{mgm}$. per cent and the blood sugar $84 \mathrm{mgm}$. per cent. The serum concentration of sodium was 138.5 m.eq., chloride $96.4 \mathrm{~m}$. eq., and potassium $6.48 \mathrm{~m}$. eq. per liter. The urine and stool were normal.

$\mathrm{X}$-rays of the heart and lungs were normal and examination of the gastro-intestinal tract gave no evidence of any organic lesion. No adrenal calcification was noted. The tuberculin test was negative in dilutions up to 1 : 1,000. An electrocardiogram showed a normal record.

Résumé of treatment with desoxy-corticosterone acetate. This patient had been receiving previously 5 grams of added sodium chloride daily and 2 cc. of adrenal cortical extract 8 injected subcutaneously. This treatment was discontinued and desoxy-corticosterone acetate treatment (15 mgm. daily) resulted in marked clinical improvement, associated with increased appetite, improved muscular strength, increased weight, and increased blood pressure. Withdrawal of desoxy-corticosterone acetate treatment (48 hours) resulted in weight loss, lowering of blood pressure, anorexia, diuresis, and a marked increase in the renal excretion of sodium and chloride. Resumption of desoxy-corticosterone acetate treatment $(20 \mathrm{mgm}$.

8 Parke, Davis and Company Eschatin. 
daily) resulted in striking improvement in the clinical condition of the patient, gain in weight, improved appetite, and strength. (Data are given in the corresponding charts and tables of the text.) At no time during this study was added sodium chloride administered. At present this patient is being maintained on $10 \mathrm{mgm}$. of desoxy-corticosterone acetate daily without added sodium chloride therapy.

E. V. (Number 116221), a Greek male store clerk, 39 years of age, was admitted to the Johns Hopkins Hospital, August 10, 1937, complaining of abdominal pain, progressive weakness, and darkening of the skin. During the 2 years prior to his present admission, his skin had become darker and he had had recurrent attacks of nausea and vomiting with slowly progressive weakness. During this present illness he had lost $12.7 \mathrm{kgm}$.

On admission, the patient was found to be very weak, and there was evidence of marked weight loss. His temperature was $99^{\circ} \mathrm{F}$., pulse rate 88 , respirations 24 , and body weight $51.9 \mathrm{kgm}$. His skin was uniformly dark brown, with an increase in the degree of pigmentation in the folds of the axillae and palms. There was a diffuse black speckled pigmentation on the buccal mucous membrane. The blood pressure was $78 / 44 \mathrm{~mm}$. $\mathrm{Hg}$ and the heart sounds were very distant.

Laboratory examination on admission revealed the following: Hemoglobin 74 per cent, red blood cells 4.34 million, white blood cells 3,880 , polymorphonuclears 59 per cent, lymphocytes 32 per cent, monocytes 4 per cent, eosinophils 1 per cent, basophils 4 per cent. The urine was normal. The blood Wassermann was negative. The fasting blood sugar was $90 \mathrm{mgm}$. per cent, the blood nonprotein nitrogen $60 \mathrm{mgm}$. per cent, and the plasma concentration of sodium 130.7 m.eq., chloride 97.4 m.eq., and potassium $4 \mathrm{~m}$. eq. per liter. $\mathrm{X}$-rays of the chest and abdomen were negative. A tuberculin test was positive $0.001 \mathrm{mgm}$.).

On a high sodium, low potassium diet, the patient gained strength and weight, and the plasma electrolytes returned to a normal concentration in 1 week. The patient was discharged August 25, 1937, weighing 53.7 $\mathrm{kgm}$., with instructions to take 12 grams of sodium chloride daily. He continued in fair health although his appetite was poor, and he never felt strong enough to return to work. Since December 1937 the patient has received 4 cc. (160 grams of adrenal cortex) daily of injected extract ${ }^{\circ}$ and 12 grams of sodium chloride. On October 5, 1938, the patient was readmitted for desoxycorticosterone acetate therapy.

Résumé of treatment with desoxy-corticosterone acetate. Blood examination on admission revealed the following values : serum sodium 137.5 m.eq., serum chloride 103.0 m.eq., and serum potassium 5.40 m.eq. per liter, carbon dioxide combining power of the serum 53.2 volumes per cent, nonprotein nitrogen $32 \mathrm{mgm}$. per cent, blood sugar $79 \mathrm{mgm}$. per cent, hematocrit 35.8 per cent cells, and total protein 5.90 grams per cent. Withdrawal of sodium chloride and extract treatment (24 hours)

${ }^{\ominus}$ Wilson and Company adrenal cortical extract. resulted in loss of strength, hemoconcentration (the cell volume increasing from 36.0 per cent cells to 39.3 per cent cells), a marked decrease in plasma volume (from 2,560 cc. to $2,380 \mathrm{cc}$.), a marked diuresis associated with a negative sodium and chloride balance, a striking decrease in the sodium and chloride concentration of the serum, and a slight rise in the serum concentration of potassium. At this time the injection of $15 \mathrm{mgm}$. of desoxy-corticosterone acetate daily, without added sodium chloride therapy, resulted in marked clinical improvement. On 2 occasions withdrawal of desoxy-corticosterone acetate treatment (48 hours) resulted in marked weight loss, anorexia, and decrease in strength. In both instances resumption of treatment caused the prompt disappearance of these signs and symptoms. (Data are given in the corresponding charts and tables of the text.)

This patient has been treated successfully for 5 months by means of daily injections (10 to $15 \mathrm{mgm}$. per day) of desoxy-corticosterone acetate. Throughout this entire period the patient has had a normal diet with no added sodium chloride therapy. At present he is being maintained in excellent condition on a single daily injection of $10 \mathrm{mgm}$. of desoxy-corticosterone acetate without added sodium chloride. On this regimen he has returned to work for the first time in over 3 years.

P. W. (Number 150453), a 34-year-old clergyman, was admitted to the Johns Hopkins Hospital on October 5th, 1938, for treatment of Addison's disease. Generalized brownish pigmentation was first noticed in 1925. In the summer of 1932-33 he had heat cramps which were relieved by salt water. In 1934 he had an attack of nausea, vomiting, and weakness progressing to coma. At this time he was found to have a blood pressure of 70/50 $\mathrm{mm}$. Hg. Treatment with sodium chloride, glucose, and adrenal cortical extract resulted in marked improvement, and since then he has been maintained in fair health on small doses of cortical extract 10 ( 2 to 4 cc. daily representing approximately 80 to $\mathbf{1 6 0}$ grams of fresh cortex) and 8 to 10 grams of added sodium chloride daily. On 2 occasions he has been on the verge of collapse necessitating intravenous therapy.

In 1930 the patient had a severe sore throat; in 1932 a tonsillectomy was performed, and in 1934 he underwent an appendectomy.

Physical examination on October 5, 1938, revealed a white male of slight build, fairly well nourished, appearing alert, and in no discomfort. The temperature was $98.2^{\circ} \mathrm{F}$., pulse rate 84 per minute, respirations 22 per minute, and blood pressure $94 / 60 \mathrm{~mm}$. Hg. The skin was slaty brown in color with dark brown pigmentation of the face, neck, forearms, external genitalia, and gluteal folds. Over the face, neck, and shoulders were a few scattered deeply pigmented nevi. No pigmentation of the mucous membranes was observed. The external ears were hard and cartilaginous. The lungs were clear, and the heart was normal save for the heart sounds being distant.

Laboratory data on admission were as follows: The

${ }^{10} \mathrm{Wilson}$ and Company adrenal cortical extract. 
red blood cells were 4.3 million, hemoglobin 12.7 grams, white blood cells 5,000 with polymorphonuclears 69 per cent, lymphocytes 25 per cent, and monocytes 6 per cent. The sedimentation rate was $12 \mathrm{~mm}$. in 1 hour, and the volume of packed red blood cells 43 per cent. The blood Wassermann was negative. The blood nonprotein nitrogen was $38 \mathrm{mgm}$. per cent, blood sugar $65 \mathrm{mgm}$. per cent, plasma $\mathrm{CO}_{2}$ combining power 57.9 volumes per cent, serum concentration of sodium 130.5 m.eq., chloride $97.8 \mathrm{~m} . e q$. and potassium $5.16 \mathrm{~m} . e q$. per liter, and total plasma protein 7.38 grams per cent. Examinations of the urine was negative.

The basal metabolic rate was plus 4 per cent. X-ray of the heart and lungs was normal. There was no evidence of calcification in the area of the adrenals. An electrocardiographic tracing showed $\mathrm{T} 1$ isoelectric and $\mathrm{T} 2$ and $\mathrm{T} 3$ inverted.

Résumé of treatment with desoxy-corticosterone acetate. Withdrawal of sodium chloride and extract treatment (48 hours) resulted in the onset of symptoms of acute adrenal insufficiency associated with a marked lowering of blood pressure, anorexia, vomiting, a diuresis associated with an increased excretion of sodium and chloride, a further lowering of the serum concentration of sodium and chloride, and a slight rise in the serum concentration of potassium. At this time $15 \mathrm{mgm}$. of desoxy-corticosterone acetate were injected and the patient was given a single infusion of 16 grams of sodium chloride (a quantity of sodium chloride calculated to be equivalent to the negative balance of sodium chloride which had obtained during the 2 days off treatment). Subsequently the patient received 15 to $20 \mathrm{mgm}$. of desoxy-corticosterone acetate daily, no additional sodium chloride being given. The patient was maintained on this regimen for 23 days with marked clinical improvement, increased appetite, gain in body weight, and increased blood pressure. (Data are given in the corresponding charts and tables of the text.)

At this time it was decided to test the dose of desoxycorticosterone acetate which would be required when sodium chloride therapy (15 grams daily) was added to the regimen. Previous experience had shown that this patient could not be maintained on sodium chloride therapy alone. Following the addition of 15 grams of sodium chloride to the diet, it was observed that approximately 5 to $6 \mathrm{mgm}$. daily of desoxy-corticosterone acetate were sufficient to maintain him in excellent condition.

J. P. (Number 123218), a 40-year-old Italian housewife was admitted to the Johns Hopkins Hospital on October 21, 1937, complaining of weakness, weight loss, and pigmentation of the skin of 3 years' duration. The present illness began in 1934 when the patient first began to notice brownish black freckles on her forearms. This pigmentation gradually became deeper and spread until her whole body had become a chocolate brown. During the year preceding admission she had noticed increasing fatigue, weakness, and anorexia, her weight decreasing from $104.5 \mathrm{kgm}$. to $66.3 \mathrm{kgm}$. Menses had always been normal. She had had one normal pregnancy in 1920 and one miscarriage 5 months later.
Physical examination on admission revealed a woman appearing moderately weak and showing evidence of marked loss of weight. The temperature was $98.2^{\circ} \mathrm{F}$., pulse rate 72 , respirations 18 , and blood pressure 133 / $95 \mathrm{~mm}$. Hg. There was marked dark brown pigmentation of the whole body with accentuation in the flexor creases but with a striking absence of pigmentation of the palms and soles. There was a blotchy pigmentation of the lips and buccal mucous membranes. There was very mild narrowing of the retinal arteries. The heart sounds were rather distant, and a soft systolic murmur was heard at both base and apex. The peripheral vessels were soft.

The laboratory findings were as follows: Hemoglobin 13.4 grams, red blood cells 4.2 million, white blood cells 4,000 , polymorphonuclears 60 per cent, lymphocytes 36 per cent, monocytes 3 per cent, eosinophils 1 per cent, hematocrit 40 per cent cells. Specific gravity of the urine was 1.019 , and the urine contained 2 plus albumin. The blood Wassermann showed negative findings, and the blood chemistry examination revealed blood sugar $74 \mathrm{mgm}$. per cent, nonprotein nitrogen $28 \mathrm{mgm}$. per cent, plasma $\mathrm{CO}_{2} 52.2$ volumes per cent, total plasma protein 6.44 grams per cent, plasma concentration of sodium 138.6 m.eq., and chloride 100.0 m.eq. per liter. X-rays showed some non-tuberculous infiltration of the lungs, a normal heart and aorta, and no intra-abdominal calcification. Skull plates were normal. Electrocardiogram showed low voltage and an inversion of the $\mathrm{T}$-waves. Basal metabolic rate was +17 per cent.

During the first week the patient was allowed to eat as she desired without extra salt. She gradually became weaker; appetite failed; and she lost weight. On November 2, 1937, the plasma concentration of sodium was $127 \mathrm{~m}$. eq. and of chloride $91 \mathrm{~m} . e q$. , the nonprotein nitrogen had risen to $42 \mathrm{mgm}$. per cent. Hematocrit was still 40 per cent cells. Improvement followed the subcutaneous injection of extract, however, and by November 8 th the plasma sodium had risen to $138.6 \mathrm{~m}$.eq. and chloride to 99.6 m.eq.

Since January 1938, this patient received 2 cc. ( 80 grams of adrenal cortex) of injected extract ${ }^{11}$ daily in addition to the daily intake of 10 grams of sodium chloride. On a recent examination (May 8, 1938) she was found to have a systolic blood pressure of over $150 \mathrm{~mm}$. $\mathrm{Hg}$ which confirmed the suspicion that she had some degree of hypertension preceding the onset of adrenal insufficiency. On November 14, 1938, she was readmitted for trial of desoxy-corticosterone acetate therapy.

Résumé of treatment with desoxy-corticosterone acetate. Blood examination on admission revealed the following values: serum sodium 138.7 m.eq., serum chloride 100.6 m.eq. and serum potassium 4.20 m.eq. per liter, carbon dioxide combining power 55.1 volumes per cent, nonprotein nitrogen $32 \mathrm{mgm}$. per cent, sugar $83 \mathrm{mgm}$. per cent, hematocrit 41.3 per cent cells, and total protein 6.3 grams per cent. Withdrawal of sodium chloride and extract treatment (48 hours) resulted in weight loss,

11 Wilson and Company adrenal cortical extract. 
slight loss of strength, decreased appetite, hemoconcentration, and a marked reduction in the serum concentration of sodium and chloride, associated with a marked negative balance of these electrolytes. (The onset of catamenia coincided with the withdrawal of treatment.) At this time treatment with desoxy-corticosterone acetate (20 mgm. daily) without added sodium chloride therapy resulted in improved strength, appetite and sense of well-being, weight gain, and an increase in blood pressure. Subsequently, the withdrawal (3 days) of desoxycorticosterone acetate treatment resulted in a recurrence of the symptoms of adrenal insufficiency, associated with weight loss and a lowered blood pressure. Again treatment with desoxy-corticosterone acetate $(20 \mathrm{mgm}$. daily) without added sodium chloride therapy resulted in improved strength and appetite, a marked gain in weight and an increase in blood pressure. (Data are given in the corresponding charts and tables of the text.) Following this study, desoxy-corticosterone acetate treatment was discontinued, and the patient was maintained on 15 grams of sodium chloride daily. On this regimen she is able to carry on all of her household duties.

\section{BIBLIOGRAPHY}

1. Hartman, F. A., MacArthur, C. G., and Hartman, W. E., A substance which prolongs the life of adrenalectomized cats. Proc. Soc. Exper. Biol. and Med., 1927, 25, 69.

2. Rogoff, J. M., and Stewart, G. N., The influence of adrenal extracts on the survival period of adrenalectomized dogs. Science, 1927, 66, 327.

3. Pfiffner, J. J., and Swingle, W. W., The preparation of an adrenal extract of the suprarenal cortex. Anat. Rec., 1929, 44, 225.

4. Reichstein, T., Chemie des Cortins und seiner Begleitstoffe, Ergebnisse der Vitamin- und Hormonf or s chung. Akademische Verlagsgesellschaft, Leipsic, 1938, 1, 334 (Review).

5. Steiger, M., and Reichstein, T., Desoxy-corticosteron (21-oxy-progesteron) aus $\Delta^{5}$-3-oxy-ätio-cholensäure). Helvet chim. acta, 1937, 20, 1164.

6. Reichstein, T., and v. Euw, J., Uber Bestandteile der Nebennierenrinde. Isolierung der Substanzen $\mathbf{Q}$ (Desoxy-Corticosteron) und $R$ sowie wieterer Stoffe. Helvet chim. acta, 1938, 21, 1197.

7. Thorn, G. W., Engel, L. L., and Eisenberg, H., The effect of corticosterone and related compounds on the renal excretion of electrolytes. J. Exper. Med., 1938, 68, 161.

8. Thorn, G. W., and Eisenberg, H., Studies on desoxycorticosterone (a synthetic adrenal cortical hormone). Endocrinology, July 1939 (in press).

9. Loeb, R. F., Effect of sodium chloride in treatment of a patient with Addison's disease. Proc. Soc. Exper. Biol. and Med., 1933, 30, 808.

10. Harrop, G. A., Weinstein, A., Soffer, L. J., and Trescher, J. H., The diagnosis and treatment of Addison's disease. J. A. M. A., 1933, 100, 1850.
11. Wilder, R. N., Kendall, E. C., Snell, A. M., Kepler, E. J., Rynearson, E. H., and Adams, M., Intake of potassium, an important consideration in Addison's disease-a metabolic study. Arch. Int. Med., 1937, 59, 367.

12. Butler, A. M., and Tuthill, T., An application of the uranyl zinc acetate method for determination of sodium in biological material. J. Biol. Chem., 1931, 93, 171.

13. Peters, J. P., and Van Slyke, D. D., Quantitative Clinical Chemistry. Vol. II. Methods. Chapter XXX. Chloride. Williams and Wilkins Co., Baltimore, 1932, p. 829.

14. Shohl, A. T., and Bennett, H. B., A micro method for the determination of potassium as iodoplatinate. J. Biol. Chem., 1928, 78, 643.

15. Strauss, M. B., The use of thorium nitrate in the rapid ashing of serum and urine. I. Adopted for subsequent potassium determinations. J. Biol. Chem., 1937, 118, 331.

16. Van Slyke, D. D., and Cullen, G. E., Studies of acidosis. I. The bicarbonate concentration of the blood plasma, its significance and its determination as a measure of acidosis. J. Biol. Chem., 1917, 30, 288.

Van Slyke, D. D., Studies of acidosis. II. A method for the determination of carbon dioxide and carbonates in solution. J. Biol. Chem., 1917, 30, 347.

Van Slyke, D. D., and Stadie, W. C., The determination of the gases of the blood. J. Biol. Chem., 1921, 49, 1.

17. Folin, O., and Wu, H., A system of blood analysis. J. Biol. Chem., 1919, 38, 81.

18. Gregersen, M. I., and Gibson, J. G., Jr., Conditions affecting the absorption spectra of vital dyes in plasma. Am. J. Physiol., 1937, 120, 494.

19. Gibson, J. G., Jr., and Evans, W. A., Jr., Clinical studies of the blood volume. I. Clinical application of a method employing the azo dye "Evans blue" and the spectrophotometer. J. Clin. Invest., $1937,16,301$.

20. Gibson, J. G., Jr., and Evelyn, K. A., Clinical studies of the blood volume. IV. Adaptation of the method to the photoelectric microcolorimeter. J. Clin. Invest., 1938, 17, 153.

21. Evelyn, K. A., and Cipriani, A. J., A photoelectric microcolorimeter. J. Biol. Chem., 1937, 117, 365.

22. Fiske, C. H., and Subbarow, Y., The colorimetric determination of phosphorus. J. Biol. Chem., 1927, 66, 375 .

23. Thorn, G. W., Garbutt, H. T., Hitchcock, F. A., and Hartman, F. A., The effect of cortin on the sodium, potassium, chloride, inorganic phosphorus and total nitrogen balance in normal subjects and in patients with Addison's disease. Endocrinology, 1937, 21, 202.

24. Gibson, J. G., Jr., and Evans, Wm. A., Jr., Clinical studies of the blood volume. II. The relation of 
plasma and total blood volume to venous pressure, blood velocity rate, physical measurements, age and sex in 90 normal humans. J. Clin. Invest., 1937, 16, 317.

25. Thorn, G. W., and Kuhlman, D., The effect of desoxycorticosterone on carbohydrate metabolism of adrenalectomized dogs. (To be published.)

26. Levy-Simpson, S., The use of synthetic desoxy-corticosterone acetate in Addison's disease. Lancet, 1938, 2, 557.

27. Thorn, G. W., and Engel, L. L., The effect of sex hormones on the renal excretion of electrolytes. J. Exper. Med., 1938, 68, 299.

28. Kendall, E. C., Flock, E. V., Bollman, J. L., and Mann, F. C., The influence of cortin and sodium chloride on carbohydrate and mineral metabolism in adrenalectomized dogs. J. Biol. Chem., 1938, 126, 697.

29. Ingle, D. J., The effects of administering large amounts of cortin on the adrenal cortices of normal and hypophysectomized rats. Am. J. Physiol., 1938, 124, 369. 